\title{
The Effect of Freezing Sheep's Milk on the Meltability, Texture, Melting and Fat Crystallization Profiles of Fresh Pasta Filata Cheese
}

\author{
Jakub Biegalski $^{1}\left(\mathbb{D}\right.$, Dorota Cais-Sokolińska ${ }^{1, *(\mathbb{D}}$, Jolanta Tomaszewska-Gras ${ }^{2}$ (D) and Hanna M. Baranowska ${ }^{3}(\mathbb{D}$ \\ 1 Department of Dairy Products Quality, Faculty of Food Science and Nutrition, Poznań University of Life \\ Sciences, ul. Wojska Polskiego 31, 60-624 Poznań, Poland; jakub.biegalski@up.poznan.pl \\ 2 Department of Food Safety and Quality Management, Poznań University of Life Sciences, \\ ul. Wojska Polskiego 31, 60-624 Poznań, Poland; jolanta.tomaszewska-gras@up.poznan.pl \\ 3 Department of Physics and Biophysics, Poznań University of Life Sciences, ul. Wojska Polskiego 38/42, \\ 60-637 Poznań, Poland; hanna.baranowska@up.poznan.pl \\ * Correspondence: cais@up.poznan.pl; Tel.: +48-61-8487-317
}

check for updates

Citation: Biegalski, J.;

Cais-Sokolińska, D.;

Tomaszewska-Gras, J.; Baranowska, H.M. The Effect of Freezing Sheep's Milk on the Meltability, Texture, Melting and Fat Crystallization Profiles of Fresh Pasta Filata Cheese. Animals 2021, 11, 2740. https:// doi.org/10.3390/ani11092740

Academic Editor: Bianca Castiglioni

Received: 3 August 2021

Accepted: 17 September 2021

Published: 19 September 2021

Publisher's Note: MDPI stays neutral with regard to jurisdictional claims in published maps and institutional affiliations.

Copyright: (C) 2021 by the authors. Licensee MDPI, Basel, Switzerland. This article is an open access article distributed under the terms and conditions of the Creative Commons Attribution (CC BY) license (https:/ / creativecommons.org/licenses/by/ $4.0 /)$.
Simple Summary: Sheep's milk is usually produced on small farms. It is mainly used in the pro duction of cheese products. One of the methods of extending the shelf life of sheep's milk is freezing it. In this study we examined the effect of freezing on sheep's milk and a mixture of sheep's and cow's milk on the quality of fresh pasta filata cheeses produced from the milk. It has been proven that the freezing of milk affects the possibility of using it in later cheese processing. Freezing sheep's milk influenced, among others, a greater hardness and less elasticity of the cheese. We also noticed that the addition of frozen sheep's milk caused consumer dissatisfaction.

Abstract: Sheep's milk is produced in smallholdings, which hinders the continuity of production. Therefore, freezing during periods of high production can be a solution. Herein, we examined the effect of freezing on sheep's milk and a mixture of sheep and cow's milk (70:30, v/v) on the quality of fresh pasta filata cheeses produced from the milk. Frozen/thawed sheep's milk contributes little to the development of innovative and reformulated cheeses. This was due to $24 \%$ higher hardness and greater extensibility and cutting force, as well as lower stretching and elasticity. Although their flowability increased (Oiling-off from 3 to 12\%), the meltability (tube test, and Schreiber test) decreased. Additionally, the use of frozen milk caused consumer dissatisfaction. The consumer penalty analysis of the just-about-right showed that freezing of the milk caused the loss of the refreshing, elasticity and shininess of pasta filata cheeses.

Keywords: frozen milk; sheep's milk; pasta filata cheese; meltability; water mobility

\section{Introduction}

The supply of sheep's milk in many regions depends on low sheep productivity, the seasonality of milk production and the short period of lactation. In many countries, sheep's milk is produced in smallholdings, which hinders large-scale production [1]. The largest amounts of sheep's milk are produced in Asia (46.3\%) followed by Europe (29.8\%) and Africa (23.0\%). Turkey produces the greatest amount of fresh sheep's milk, followed by China (mainland) and Greece. Approximately 10.6 Mt of whole, fresh sheep's milk is produced globally [2]. Moreover, sheep's milk production is expected to increase by $26 \%(+2.7 \mathrm{Mt})$ by 2030 [3] due to the growing demand for cheese and its use in infant formulas and nutraceuticals [4,5]. For many consumers, sheep's milk and its products are considered essential for the proper functioning of the human body, and are perceived by consumers as a material with high health-promoting potential [6,7]. Therefore, in our opinion the dairy sector may also be interested in mixing sheep's milk with cow's milk. Due to the development of appropriate technologies for the processing of mixed milk of 
various mammals, it is possible to maintain or increase the amount of bioactive ingredients that are contained within [8,9]. Moreover, the use of milk mixtures from different species of mammals is consider an interesting approach to propagate dairy processing in many regions of the world [10].

Sheep's milk contains an average of $5.7 \%$ protein, $7.4 \%$ fat, $4.8 \%$ lactose and $0.9 \%$ ash [11]. The protein fractions of sheep's milk are mainly: casein $(41-46 \mathrm{~g} / \mathrm{kg}$ ) and whey proteins $(8-16 \mathrm{~g} / \mathrm{kg})$, which is in contrast to the protein fractions of cow's milk (24-28 g/ kg caseins, 5-7 g/kg whey proteins) [11,12]. Sheep's milk casein micelles have a higher degree of mineralization due to greater amount of calcium, reduced hydration and thermal stability compared to cow's milk micelles [13]. Overall, the calcium content of sheep's milk is higher (1.59-2.42 g/L) than that of cow's milk (0.90-1.84 g/L). The share of short and medium-length saturated fatty acids (FA) such as caproic (C6:0), caprylic (C8:0), capric (C10:0) and lauric (C12:0) in sheep's milk fat is much higher (14.2-17.7\%) than in cow's milk $(9.0-11.0 \%)[4,12]$. Furthermore, sheep's milk fat has low ratio of omega- 6 to omega3 (n-6: $n-3)$ FA, which is associated with the prevention of cardiovascular diseases and cancer. Sheep's milk may contain higher amounts of omega(n)-3, polyunsaturated fatty acid (PUFA) and biohydrogenation intermediate PUFA, including conjugated linoleic acid and trans-mono-unsaturated FA, vaccenic acid, rumenic acid and branched FA compared to cow's milk [12]. The high CLA content in sheep's milk, compared to the milk of other ruminants, is of particular interest for the prevention of cancer diseases. It is also known that sheep's milk contains higher amounts of vitamin A (40-84 $\mu \mathrm{g} / 100 \mathrm{~g})$ and D $(0.18 \mu \mathrm{g} / 100 \mathrm{~g})$ than cow's milk (29-52 $\mu \mathrm{g} / 100 \mathrm{~g}$ and 0.03-1 $\mu \mathrm{g} / 100 \mathrm{~g}$, respectively) [12]. The characteristic composition of sheep's milk and its role in many nutritional interventions make it increasingly sought after by consumers.

However, the limited supply of sheep's milk necessitates the collection of this raw material and the use of alternative storage techniques to ensure the continuity of production in the dairy plant. A general solution is to freeze sheep's milk. The freezing time strictly depends on the cooling rate, the initial quality of the milk used in production and the final storage temperature [14]. Milk should be immediately chilled and frozen as soon as possible in order to reduce the growth of microorganisms and enzyme activity [15]. The freezing process can significantly affect the fat globules, promoting the release of lipoproteins and diminish stability of the lipid phase [14,15]. Additionally, the process increases the particle size, which leads to the coalescence and natural separation of the cream, as well as an increased rate of fat oxidation and the occurrence of lipolysis [16,17]. Freezing can also greatly affect the destabilization of proteins with a micellar nature, which depend on the temperature. For example, the destabilization of sheep's milk proteins at $-15{ }^{\circ} \mathrm{C}$ occurs after 6 months of storage, and at $-27{ }^{\circ} \mathrm{C}$ after 12 months [18]. The destabilization of milk proteins consequently leads to casein aggregation and reduction of the water holding capacity (WHC). This is directly influenced by the breaking of hydrogen bonds between polypeptides [1].

However, to date, there are no studies that examine the influence of freezing on sheep's milk or a mixture with cow's milk, and its effects on the quality of fresh pasta filata cheeses prepared from the milk. Albenzio et al. [19] and Tripaldi et al. [20] described the growing interest in sheep's milk pasta filata cheese, even though sheep's milk generally has poor stretching ability [21]. Herein, we examined whether freezing sheep's milk can cause changes in the texture, meltability, water activity, water mobility, crystallization, melting and thermal oxidation of fat. Differential scanning calorimetry (DSC) was used to elaborate the water-protein-fat interactions in pasta filata cheeses, and nuclear magnetic resonance (NMR) relaxation techniques were used to assess the mobility of water. We present these properties on the background of sensory attractiveness from the consumers' perception, which was investigated in detail. 


\section{Materials and Methods}

\subsection{Sheep's and Cow's Milk Samples}

The research material was fresh, raw, full sheep's milk collected from Polish Dairy sheep line 05 (average body weight of ewes was $60 \mathrm{~kg} \pm 5.5 \mathrm{~kg}$ and aged 3,4 and 5 years) purchased from local farmers in Greater Poland (52 L). Milk was collected from sheep in the months from May to September 2020. Half of the milk was frozen in $5 \mathrm{~L}$ PP bottles (milk volume up to $4.5 \mathrm{~L}, \varnothing=16 \mathrm{~cm}, \mathrm{~h}=40 \mathrm{~cm}$ ) at $-24^{\circ} \mathrm{C}$ in Fiocchetti Super-Polo freezer (C.F. di Ciro Fiocchetti \& C. s.n.c., Luzzara, Italy). Storage time was 12 weeks. The milk was thawed immediately before further processing. Milk from Holstein-Friesian cows was also used. It was high hygienic and cytological quality milk intended for dairy plants. A total of $260 \mathrm{~L}$ of sheep's milk and $260 \mathrm{~L}$ of cow's milk were used.

\subsection{Mixture of Milk}

Cow's milk was combined in the proportion of 70:30 $(v / v)$ with fresh sheep's milk and in the same proportion with frozen milk after thawing.

\subsection{Cheese Preparation Protocols}

The production of pasta filata cheese involves normalization and pasteurization of milk or a mixture of cow's and sheep's milk, and production of the curd and its acidification, followed texturization of the acidified curd, which involves heating, kneading, and stretching by soaking the curd in hot water. The milk or milk mixture was pasteurized $\left(75{ }^{\circ} \mathrm{C}, 15 \mathrm{~s}\right.$ ) in MILKY FJ15 (Franz Janschitz GmbH, Althofen, Austria). After cooling to $40{ }^{\circ} \mathrm{C}$, thermophilic starter culture Lyofast SAB $440 \mathrm{~B}$ of Sacco (Cadorago, Italy) was added to the milk in an amount of $8 \mathrm{UC}$ (dosage units) to $20 \mathrm{~L}$ of milk. The starter culture consisted of: Streptococcus thermophilus, Lactobacillus acidophilus and Bifidobacterium animalis subsp. lactis. At pH 6.5, Beaugel 5 rennet (Ets COQUARD, Villefranche Sur Saône, France) with a chymosin activity above $150 \mathrm{mg} / \mathrm{L}$ at a strength of $1 / 3000$ was added in the amount of $14 \mathrm{~mL}$ per $20 \mathrm{~L}$ of milk. This amount was used to form the curd after $30 \mathrm{~min}$. The curd was cut into $1 \times 1 \mathrm{~cm}$ cubes and set aside for $20 \mathrm{~min}$ until $\mathrm{pH} 5.9$ was reached. The cheese curd was drained at $23^{\circ} \mathrm{C}$ for $2 \mathrm{~h}$ to $\mathrm{pH}$ 5.2. Plasticization (kneading and stretching) was carried out in water with salt $\left(77-80^{\circ} \mathrm{C}\right)$. The formed cheese was cooled in water with salt $\left(16 \%, 12^{\circ} \mathrm{C}\right)$. The cheese was packed with a brine and stored at $3{ }^{\circ} \mathrm{C}$ in the form of spheres with a weight of $220 \mathrm{~g}$. The range of changes of cheese quality features of the model were rated after 2 days of manufacturing at $3 \pm 0.5^{\circ} \mathrm{C}$ storage.

Test specimens were taken from different production batches $(n=5)$. Approximately $3.8 \mathrm{~kg}$ cheese ( 17 balls) was obtained from $20 \mathrm{~L}$ of milk. Each ball of cheese was $220 \mathrm{~g}$. The cheese was prepared in pilot plant scale using pilot industrial equipment, and each batch was analyzed twice.

\subsection{Composition and Freezing Point}

A Bentley DairySpec FT Manual (Bentley Instruments, Inc., Chaska, MN, USA) was used to determine the composition of the studied milk. The composition of the cheese was determined according to moisture [22], protein, and fat [23] content. Total protein $(\mathrm{TN}-\mathrm{NPN}) \times 6.38 ; \mathrm{C}=$ casein $(\mathrm{TN}-\mathrm{NCN}-\mathrm{NPN}) \times 6.38 ; \mathrm{WP}=$ whey protein $(\mathrm{NCN}-\mathrm{NPN})$ $\times$ 6.38. The freezing point of the studied milk was determined according to ISO 5764 [24] standard method using an Advanced Model 4D3 cryoscope with 3LH700 thermistor probe (Advanced Instruments Inc., Norwood, MA, USA).

\subsection{Acidity and Conductivity}

$\mathrm{pH}$ was measured using a CP-402 pH-meter (Elmetron, Zabrze, Poland) equipped with a IONODE IJ44A electrode (Ionode Pty. Ltd., Tennyson, Australia). The titratable acidity values were expressed as Soxhlet-Henkel degree $\left({ }^{\circ} \mathrm{SH}, 1^{\circ} \mathrm{SH}=0.0225\right.$ lactic acid $\%$ ). Conductivity was measured using a CP-505 conductometer (Elmetron, Zabrze, Poland) equipped with a EC-60 conductometric sensor (Elmetron, Zabrze, Poland). 


\subsection{Water Activity}

The water activity was measured with an AquaLab Series 4TE instrument (Decagon Devices Inc., Pullman, WA, USA). The following salt solutions were used for reference:

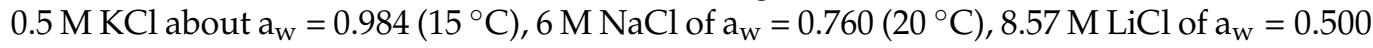
$\left(25^{\circ} \mathrm{C}\right)$ and $13.41 \mathrm{M} \mathrm{LiCl}$ of $\mathrm{a}_{\mathrm{w}}=0.250\left(25^{\circ} \mathrm{C}\right)$. Samples of $\mathrm{v}=15 \mathrm{~mL}$ were placed in a DE 501 measurement vessel (Decagon Devices Inc., Pullman, WA, USA) and tested at $15^{\circ} \mathrm{C}$.

\subsection{Viscosity}

Absolute values of dynamic viscosity of the studied milk were recorded using a Hőppler KF10 viscosimeter by RheoTec Messtechnik GmbH (Ottendorf, Germany). The time (s) was measured (t) for a ball to fall over a distance of $100 \mathrm{~mm}$ at an inclination angle of $70^{\circ}$ within a volume $\mathrm{v}=40 \mathrm{~mL}$. The angle constant for the measurement was $\mathrm{FH}=0.952(-)$. Balls used in the tests were made from $\mathrm{Fe}-\mathrm{Ni}$ alloy with diameters of $\varnothing \mathrm{k} 3=15.552 \mathrm{~mm}$ and $\varnothing \mathrm{k} 4=15.199 \mathrm{~mm}$ and mass of $\mathrm{mk} 3=16.0627 \mathrm{~g}$ and $\mathrm{mk} 4=14.1797 \mathrm{~g}$, density of $\mathrm{dk} 3=8.156 \mathrm{~g} / \mathrm{mL}$ and $\mathrm{dk} 4=7.713 \mathrm{~g} / \mathrm{mL}$ at the apparatus constants ascribed based on the certificate $\mathrm{K} 3=0.13543 \mathrm{mPa} \cdot \mathrm{mL} / \mathrm{g}$ and $\mathrm{K} 4=1.2268 \mathrm{mPa} \cdot \mathrm{mL} / \mathrm{g}$. On the basis of sample density (dp), established using an areometer by Areometr (Warszawa, Poland) at fiducial temperature $\left(\mathrm{T}=20^{\circ} \mathrm{C}\right)$ within the range from 1015 to $1045 \mathrm{~g} / \mathrm{mL}$ dynamic viscosity was calculated using Equation (1):

$$
\eta=t \times(d k-d p) \times K \times F(\mathrm{mPa} \cdot \mathrm{s})
$$

\subsection{Texture Profile Analyses}

The measurement of selected cheese texture parameters was performed using a texturometer (Stable Micro Systems Ltd., Surrey, UK) using: P/1S-firmness and stickiness (pre-test speed $1.5 \mathrm{~mm} / \mathrm{s}$, test speed $2.0 \mathrm{~mm} / \mathrm{s}$, post-test speed $10.0 \mathrm{~mm} / \mathrm{s}$, distance $5 \mathrm{~mm}$ ), $\mathrm{P} / 5$-softness (pre-test speed $2.0 \mathrm{~mm} / \mathrm{s}$, test speed $1.0 \mathrm{~mm} / \mathrm{s}$, post-test speed $1.0 \mathrm{~mm} / \mathrm{s}$, distance $10 \mathrm{~mm}$ ), A/BC-firmness (pre-test speed $0.5 \mathrm{~mm} / \mathrm{s}$, test speed $0.5 \mathrm{~mm} / \mathrm{s}$, post-test speed $10.0 \mathrm{~mm} / \mathrm{s}$, distance $25.0 \mathrm{~mm}$ ) and A/WEG—hardness and brittleness (pre-test speed $1.0 \mathrm{~mm} / \mathrm{s}$, test speed $2.0 \mathrm{~mm} / \mathrm{s}$, post-test speed $10.0 \mathrm{~mm} / \mathrm{s}$, distance $10.0 \mathrm{~mm}$ ). Results were recorded using Texture Exponent E32 version 4.0.9.0 software (Godalming, Surrey, UK).

\subsection{Meltability}

Meltability of cheese was determined by two methods: the Schreiber test and test tube method [25]. For the Schreiber test a circular cookie cutter, $39.5 \mathrm{~mm}$ in diameter, was used to cut $5 \mathrm{~mm}$ high disc of cheese. This disc was placed in a covered $15 \mathrm{~mm} \times 100 \mathrm{~mm}$ thin-walled Pyrex Petri dish and heated in a forced draft oven preheated to $232{ }^{\circ} \mathrm{C}$ for $5 \mathrm{~min}$. Specimen expansion was measured using a scale having six lines marked on a concentric set of circles. The Schreiber test meltability was given as the mean of six readings on the arbitrary scale of $0-10$ units.

In the case of the test tube method, $10 \mathrm{~g}$ of grated cheese was placed in a tube $(32 \mathrm{~mm} \times 250 \mathrm{~mm}$ ) and packed to form a plug at the bottom. The height of cheese was marked. The test tube was kept vertically in a refrigerator at $4{ }^{\circ} \mathrm{C}$ for $30 \mathrm{~min}$ and then horizontally in an oven heated at $104{ }^{\circ} \mathrm{C}$ for $60 \mathrm{~min}$. Meltability was measured as flow distance in $\mathrm{mm}$ of melted cheese.

\subsection{Oiling-Off}

Oiling-off (fat-ring test) was determined according to the method described by Schenkel et al. [26] and Hartmann et al. [27]. Grated cheese samples were prepared and weighed $(5 \mathrm{~g})$ into stainless steel rings $\varnothing=36 \mathrm{~mm}$, which were placed in a glass Petri dish on to filter paper (pore size from 5 to $13 \mu \mathrm{m}, 88 \mathrm{~s}$ medium speed filtration according to DIN 53137, LLG-Labware, Meckenheim, Germany). After heat treatment at $100{ }^{\circ} \mathrm{C}$ for $7 \mathrm{~min}$ in an oven WTB Binder (Tuttlingen, Germany), the steel ring was removed. The 
sample was cooled for $5 \mathrm{~min}$ at ambient temperature and then a picture was taken. The free oil formation was expressed as the percentage of the area soaked by free oil relative to the area of the total filter paper.

\subsection{Differential Scanning Calorimetry (DSC)}

DSC was conducted using a Perkin Elmer DSC 7 differential scanning calorimeter (Perkin Elmer, Norwalk, CT, USA) equipped with an Intracooler II and running under Pyris software. Samples of cheese (9-10 mg) were weighed into aluminum pans of $20 \mu \mathrm{L}$ (Perkin Elmer, No. 0219-0062) and hermetically sealed. The sample pan was placed in the calorimeter at $5^{\circ} \mathrm{C}$ and then subjected to the following process-temperature program: (1) heating and isotherm for $5 \mathrm{~min}$ at $70^{\circ} \mathrm{C}$ to melt all crystals and nuclei; (2) cooling at $5{ }^{\circ} \mathrm{C} / \mathrm{min}$ to $-40^{\circ} \mathrm{C}$; and (3) heating at $5^{\circ} \mathrm{C} / \mathrm{min}$ to $70^{\circ} \mathrm{C}$. The following parameters were analyzed from the first melting curve: $\mathrm{T} 1_{\text {on }}$ - onset temperature, $\mathrm{T} 1, \mathrm{~T} 2$ - peak temperatures, $\mathrm{T} 1_{\text {end }}$ - final melting temperature, and enthalpy of milk fat melting $\Delta \mathrm{H}_{\mathrm{m} 1}(\mathrm{~J} / \mathrm{g})$ determined as the area limited by the melting curve and the base line. The onset temperature $\left(\mathrm{T}_{\mathrm{on}}\right)$ was taken at the intersection of the baseline with the tangent to the left side of the melting peak. From the second melting scan the temperatures of ice melting $\mathrm{Ti}_{\text {onset }}, \mathrm{Ti}_{\text {peak }}$ and enthalpy $\Delta \mathrm{H}_{\text {ice }}$ of ice melting, calculated per $1 \mathrm{~g}$ of water were measured. The percentage of unfrozen water in the water fraction (UFW) was calculated using Equation (2):

$$
U F W=100-\left(\frac{\Delta H_{i c e}}{\Delta H_{\text {ref }}}\right) \times 100(\%)
$$

where $\Delta \mathrm{H}_{\text {ice }}$ is the enthalpy of ice melting per unit mass of water contained in cheese $(\mathrm{J} / \mathrm{g})$, $\Delta \mathrm{H}_{\text {ref }}$ is the enthalpy of ice melting for samples of pure water, equal to $333.7 \mathrm{~J} / \mathrm{g}$.

\subsection{Nuclear Magnetic Resonance (NMR)}

The samples of $1.5 \mathrm{~cm}$ diameter and $1.2 \mathrm{~cm}$ height were placed in measuring test tubes and sealed using Parafilm. Measurements of the spin-lattice $\left(\mathrm{T}_{1}\right)$ and spin-spin $\left(\mathrm{T}_{2}\right)$ relaxation times were performed using a pulse NMR spectrometer operating at $30 \mathrm{MHz}$ (WL Electronics, Poland). The inversion-recovery $(\pi-\mathrm{TI}-\pi / 2)$ impulse sequence was applied for measurements of $\mathrm{T}_{1}$ relaxation times. Distances between impulses (TI) were changed within the range of 4 to $800 \mathrm{~ms}$ and repetition time of $15 \mathrm{~s}$. Each time, 32 free induction decay (FID) signals and 119 points from each FID signal were collected. Calculations of the spin-lattice relaxation time values were performed with CracSpin program using spin grouping approach [28]. Time changes of the current value of FID signal amplitude in the employed frequency of impulses were described using Equation (3):

$$
M_{z}(T I)=M_{0} \times\left(1-2 e^{\frac{-T I}{T_{1}}}\right)
$$

where $\mathrm{M}_{\mathrm{Z}}(\mathrm{TI})$ is the actual magnetization value, $\mathrm{M}_{0}$ is the equilibrium magnetization value, $\mathrm{TI}$ is the distance between impulses, and $\mathrm{T}_{1}$ is the time of relaxation.

A monoexponential magnetization recovery was found, which means that the system relaxes with one $T_{1}$ spin-lattice relaxation time. Measurements of $T_{2}$ spin-spin relaxation times were taken using the pulse train of the Carr-Purcell-Meiboom-Gill spin echoes $\left(\pi / 2-\mathrm{TE} / 2-(\pi)_{\mathrm{v}}\right)$. The distance between $\pi$ (TE) impulses amounted to $1 \mathrm{~ms}$. The repetition time was $15 \mathrm{~s}$. The number of spin echoes (n) amounted to 50. Ten accumulation signals were employed. To calculate the spin-spin relaxation time values, Equation (4) was used [29]:

$$
M_{x, y}(T E)=M_{0} \sum_{i=1}^{n} p_{1} e^{\frac{-T E}{T_{2 i}}}
$$

where $\mathrm{M}_{x, y}(\mathrm{TE})$ is the echo amplitude; $\mathrm{M}_{\mathrm{o}}$ is the equilibrium amplitude; TE is the distance between $\pi$; impulses; $p_{i}$ is the fraction of protons relaxing with the $T_{2 i}$ spin-spin time. 


\subsection{Acceptability of Appearance and Consumer Penalty Analysis}

In the sensory test, consumers $\left(n=97\right.$; ages 20 to $\left.62 ; \mathrm{M}_{\mathrm{age}}=34, \mathrm{SD}=9.57\right)$ were asked to indicate how much they liked or disliked each product on a 9-point hedonic scale ( 9 = like extremely; 1 = dislike extremely). Samples of $10 \mathrm{~g}\left(10-12{ }^{\circ} \mathrm{C}\right)$ were served. They were evaluated using a 5-point just-about-right (JAR) scale anchored at both extremes $(1=$ not enough to $5=$ too $\mathrm{much})$, with a central point at $3(3=$ ideal): aroma (acidity), flavor (refreshing, sweet milk), texture (elasticity, smoothness) and appearance (shininess).

\subsection{Statistical Analyses}

The influence of the composition on the samples was evaluated by one-way analysis of variance (ANOVA) followed by Tukey's HSD post hoc test for multiple comparisons. Data were analyzed using TIBCO Statistica data analysis software, version 13.3.0 (TIBCO Software Inc., Palo Alto, CA, USA). A critical level of significance of $\alpha=0.05$ was used throughout this study.

\section{Results and Discussion}

\subsection{Composition and Physicochemical Properties of Milk and Fresh Pasta Filata Cheese}

The sheep's milk, compared to the cow's milk, contained more solid nonfat (by $45 \%, p<0.05$, Table 1). The casein content in the sheep's milk was $41.8 \mathrm{~g} / \mathrm{kg}$, which was $54 \%$ more than in cow's milk. Caboni et al. [30] showed that the casein content in sheep's milk ranges from 36.8 to $40.8 \mathrm{~g} / \mathrm{kg}$. Additionally, they indicated that the fat/protein ratio was 0.87-1.04. Compared to our results (1.68) this was considerably lower. The different technological parameters of concern between our examined sheep's and cow's milk included freezing point, viscosity, density, and water activity $(p<0.05)$. Compared to our results, the Bučević-Popović et al. [31] tested sheep's milk showed a lower density $\left(1.0263 \mathrm{~kg} / \mathrm{m}^{3}\right)$, similar acidity $(0.24 \%$ lactic acid) and lower $\mathrm{pH} 6.45$. Sheep's milk examined by Faccia et al. [32] had a pH of 6.62. In our study, the conductivity of sheep's milk $(3.85 \mathrm{mS} / \mathrm{cm})$ was lower by almost $7 \%$ than that of cow's milk $(4.12 \mathrm{mS} / \mathrm{cm})$. This was probably due to approximately double the fat content in sheep's milk $(86.1 \mathrm{~g} / \mathrm{kg})$ than in cow's milk $(p<0.05)$. According to various reports, the fat content of sheep's milk varies widely from 3.8\% [33] to 6.48\% [34]. Yanthi et al. [35] demonstrated that the conductivity of cow's milk at $4.59 \mathrm{mS} / \mathrm{cm}$ possessed $3.05 \%$ fat content and $2.81 \%$ protein content. Additionally, they indicated that the ingredients had a significant effect on the conductivity of cow's milk such as total solid, solid nonfat, lactose and freeze point deviation. Moreover, Kaşikçi et al. [36] reported that higher conductivity was related to the mineral content in milk. Factors such as milk temperature, $\mathrm{pH}$ and fat content also influenced the conductivity value [37]. Furthermore, differences in composition, fat, protein, vitamins and minerals affected the conductivity value. In general, conductivity is influenced, among others, by lactose [35]. Fahmid et al. [38], reported that a low lactose concentration in milk can increase the conductivity value, which is reflected in the research presented in this paper. High conductivity in milk impedes the analysis of low frequency relaxations and contributes to a significant electrode polarization in dielectric measurement, as described by Agranovich et al. [39]. We used a nuclear magnetic resonance (NMR) technique to assess the structural and dynamic importance of water.

Milk is a complex colloidal liquid exhibiting a multiscaled structure, and the differences in properties and composition between sheep's and cow's milk, mainly fat/protein content and proportions, are responsible for different cheese parameters. In addition, factors such as larger casein micelles, greater calcium per casein weight, and mineral content in sheep's milk will ultimately influence the coagulation time, coagulation rate, and the amount of rennet needed [21]. 
Table 1. Composition and technological parameters of raw cow's and sheep's milk.

\begin{tabular}{|c|c|c|c|c|c|}
\hline \multirow{2}{*}{ Parameters } & \multirow{2}{*}{$\begin{array}{c}\text { Cow's Milk } \\
\text { Mean }\end{array}$} & \multicolumn{3}{|c|}{ Sheep's Milk } & \multirow{2}{*}{ SEM } \\
\hline & & $\mathbf{P}_{5}-\mathbf{P}_{95}$ & Mean & $\mathbf{P}_{5}-\mathbf{P}_{95}$ & \\
\hline Solids-not-fat (g/kg) & $83.4^{\mathrm{a}}$ & $82.9-83.8$ & $121.1^{b}$ & $120.8-121.3$ & 0.074 \\
\hline Fat $(\mathrm{g} / \mathrm{kg})$ & $46.3^{\mathrm{a}}$ & $46.1-46.5$ & $86.1^{\mathrm{b}}$ & $85.8-86.4$ & 0.037 \\
\hline Casein $(\mathrm{g} / \mathrm{kg})$ & $27.1^{\mathrm{a}}$ & $26.8-27.4$ & $41.8^{\mathrm{b}}$ & $41.5-42.0$ & 0.044 \\
\hline Whey protein $(\mathrm{g} / \mathrm{kg})$ & $6.4^{\mathrm{a}}$ & $6.1-6.7$ & $9.5^{\mathrm{b}}$ & $9.2-9.8$ & 0.048 \\
\hline Lactose $(\mathrm{g} / \mathrm{kg})$ & $43.6^{\mathrm{a}}$ & $43.3-43.8$ & $47.1^{\mathrm{b}}$ & $46.9-47.4$ & 0.035 \\
\hline Fat/protein & 1.4 & & 1.7 & & \\
\hline Ash (g/kg) & $6.8^{\mathrm{a}}$ & $6.6-7.0$ & $9.1^{\mathrm{b}}$ & 8.9-9.3 & 0.024 \\
\hline $\mathrm{pH}$ & $6.64^{\mathrm{a}}$ & $6.60-6.67$ & $6.65^{\mathrm{a}}$ & $6.62-6.67$ & 0.000 \\
\hline Titratable acidity (\% lactic acid) & $0.162^{\mathrm{a}}$ & $0.160-0.165$ & $0.216^{b}$ & $0.214-0.218$ & 0.000 \\
\hline Conductivity $(\mathrm{mS} / \mathrm{cm})$ & $4.12^{\mathrm{b}}$ & $4.10-4.14$ & $3.85^{\mathrm{a}}$ & $3.82-3.89$ & 0.001 \\
\hline Freezing point $\left({ }^{\circ} \mathrm{C}\right)$ & $-0.528^{b}$ & $-0.533--0.523$ & $-0.571^{\mathrm{a}}$ & $-0.574--0.568$ & 0.000 \\
\hline Viscosity $(\mathrm{mPa} \cdot \mathrm{s})$ & $4.22^{\mathrm{a}}$ & $4.18-4.27$ & $6.71^{b}$ & $6.68-6.75$ & 0.001 \\
\hline Density, in $20^{\circ} \mathrm{C}\left(\mathrm{kg} / \mathrm{m}^{3}\right)$ & $1.031^{\mathrm{a}}$ & $1.029-1.034$ & $1.037^{\mathrm{b}}$ & $1.033-1.040$ & 0.000 \\
\hline Water activity & $0.9838^{b}$ & $0.9836-0.9839$ & $0.9761^{a}$ & $0.9759-0.9763$ & 0.000 \\
\hline
\end{tabular}

${ }^{\mathrm{a}-\mathrm{b}}$ Means within a row with different superscripts differ $(p<0.05) ; \mathrm{P}_{5}-\mathrm{P}_{95}$ : confidence interval of the mean; SEM: standard error of the mean $(n=5)$.

The initial fluctuations in the composition of sheep's and cow's milk influenced the moisture content of the final cheese product (Table 2). Pasta filata cheeses from unfrozen and frozen sheep's milk had a moisture content of $488.8 \mathrm{~g} / \mathrm{kg}$ and $491.1 \mathrm{~g} / \mathrm{kg}$, respectively $(p>0.05)$. The mixture of cow's and sheep's milk (70:30) resulted in cheeses with a moisture content of approximately $570 \mathrm{~g} / \mathrm{kg}$. Therefore, the proportion of fat:dry matter, assuming that standardized milk was used in the experiment, ranges from 0.37 (sheep's milk cheese) to 0.48 (cow's milk cheese). The proportion of protein:dry matter was 0.53 and 0.44 , respectively.

Table 2. Composition and physicochemical properties of pasta filata cheeses from frozen cow's and sheep's milk.

\begin{tabular}{|c|c|c|c|c|c|c|}
\hline \multirow{2}{*}{ Parameters } & \multicolumn{5}{|c|}{ Pasta Filata Cheese } & \multirow{2}{*}{ SEM } \\
\hline & $\mathrm{C}$ & CS & CSF & $\mathbf{S}$ & SF & \\
\hline Moisture (g/kg) & $602.7^{c}$ & $568.5^{b}$ & $569.2^{b}$ & $488.8^{\mathrm{a}}$ & $491.1^{\mathrm{a}}$ & 0.169 \\
\hline Fat $(\mathrm{g} / \mathrm{kg})$ & $190.5^{\mathrm{a}}$ & $188.6^{\mathrm{a}}$ & $189.7^{a}$ & $189.3^{\mathrm{a}}$ & $191.4^{\mathrm{a}}$ & 0.078 \\
\hline Fat/dry matter $(w / w)$ & 0.48 & 0.44 & 0.44 & 0.37 & 0.38 & \\
\hline Protein $(\mathrm{g} / \mathrm{kg})$ & $174.2^{\mathrm{a}}$ & $204.1^{b}$ & $198.7^{b}$ & $266.8^{c}$ & $270.3^{c}$ & 0.069 \\
\hline Protein/dry matter $(w / w)$ & 0.44 & 0.47 & 0.46 & 0.52 & 0.53 & \\
\hline Protein $/$ fat $(w / w)$ & 0.9 & 1.1 & 1.1 & 1.4 & 1.4 & \\
\hline Salt $(\mathrm{g} / \mathrm{kg})$ & $0.47^{\mathrm{a}}$ & $0.46^{\mathrm{a}}$ & $0.45^{\mathrm{a}}$ & $0.46^{\mathrm{a}}$ & $0.46^{\mathrm{a}}$ & 0.000 \\
\hline $\mathrm{pH}$ & $5.13^{\mathrm{a}}$ & $5.12^{\mathrm{a}}$ & $5.11^{\mathrm{a}}$ & $5.12^{\mathrm{a}}$ & $5.12^{\mathrm{a}}$ & 0.000 \\
\hline Acidity (\% lactic acid) & $0.702^{\mathrm{a}}$ & $0.709^{a}$ & $0.695^{\mathrm{a}}$ & $0.716^{\mathrm{a}}$ & $0.702^{\mathrm{a}}$ & 0.000 \\
\hline Water activity & $0.9605^{\mathrm{a}}$ & $0.9586^{\mathrm{a}}$ & $0.9714^{b}$ & $0.9614^{\mathrm{a}}$ & $0.9773^{b}$ & 0.000 \\
\hline
\end{tabular}

${ }^{\mathrm{a}-\mathrm{c}}$ Means within a row with different superscripts differ $(p<0.05)$; SEM: standard error of the mean $(n=5)$; C: from cow's milk; CS: from cow's and unfrozen sheep's milk in proportion 70:30; CSF: from cow's and frozen sheep's milk in proportion 70:30; S: from unfrozen sheep's milk; SF: from frozen sheep's milk.

Our study showed the possibility of producing quality pasta filata cheeses from frozen/thawed sheep's milk. A model curd was produced from this milk, which was acidified and kneaded in hot water. The pasta filata cheeses were visually rindless, smooth, elastic with a long-stranded, parallel-orientated fibrous protein structure without evidence of curd granules. The plastic consistency characteristic of such cheeses had been obtained [21]. Our cheeses were ascribed to the soft cheese category of Codex Alimentarius [40].

Utilization of animal milk in this manner concurs with low supply, overcoming the seasonality of milk production, low production and short lactation periods. Yu et al. [41] showed that when using goat's milk the optimal approach to maintain the natural qual- 
ity of milk involves ultra-cryogenic freezing-homeothermic thawing. According to Nurliyani et al. [42], goat's milk should be stored at $-20{ }^{\circ} \mathrm{C}$ for up to 30 days. However, in the case of sheep's milk, storage time could be extended significantly longer. Yogurt produced from frozen sheep's milk stored for 6 months at $-20{ }^{\circ} \mathrm{C}$ did not differ in $\mathrm{pH}$, acidity, lactose, appearance and color, body and texture, flavor, overall acceptability, consistency, apparent viscosity or syneresis from sheep's unfrozen milk yoghurt [43]. Voutsinas et al. [44] brined soft cheese from ultrafiltered and frozen sheep's milk (at $-20{ }^{\circ} \mathrm{C}$ up to 6 months), which displayed a sandy texture, received lower scores for appearance, were harder and more acidic in flavor, and ranked lower in overall quality. Therefore, the production of brined soft cheese from ultrafiltered and frozen sheep's milk does not seem viable for commercial use.

Pasta filata cheeses from sheep's milk (samples $S$ ) had a higher (1.4) protein:fat ratio than (0.9) pasta filata fior di latte cheeses also from sheep's milk [32]. The $\mathrm{pH}$ of both cheeses was similar (5.12 and 5.16, respectively). In contrast, the protein:fat ratio was more similar to that of 1.2 in pasta filata-mozzarella cheeses with moisture 581.2 and $612.7 \mathrm{~g} / \mathrm{kg}$ [20]. The activities most significant in the cheese production technology, such as stretching and molding phases, have a significant effect on moisture and fat losses in the fresh curd [45].

The water activity of the cheeses was not affected by milk, but only by freezing (Table 2). Frozen sheep's milk cheeses and cheeses from a mixture of cow's milk with frozen sheep's milk had higher $(p<0.05)$ water activity than other cheeses. Hence, the structural and dynamic importance of water in frozen milk was crucial. Agranovich et al. [39] examined the individual contribution of lactose, fat and protein (mainly casein) content toward the total relaxation pattern during the dielectric spectroscopy study of water dynamics in frozen bovine milk. Our study used $5 \mathrm{~L}$ packages for freezing, therefore, the phase transition time was as short as possible and ensured a low amount of ice crystals. Large ice crystals could damage fat globules [16] and, thus, fat loss during curd stretching in pasta filata cheese production. The longer the phase change time, the slower the formation of ice crystals, which increased migration of calcium out of the micelles, as well as the concentration of soluble calcium [46]. Thermal histories of the sheep's milk freezing process in different packages, including 5 L packages, have been presented by Tribst et al. [47].

\subsection{Texture Profile, Meltability and Stretching}

The addition of frozen sheep's milk to cow's milk effected all the measured parameters of the cheeses texture (Table 3, $p<0.05$ ). Extensibility force, hardness and cutting force increased. Distance at break, meaning the brittleness of pasta filata cheeses made from the mixture, decreased by $4 \%$, while stretching decreased from 131.4 to $129.8 \mathrm{~mm}$. In the case of cheeses made only from sheep's milk, freezing of the milk did not affect stretching $(p>0.05)$. In the analysis of the texture profile of these cheeses, it was found that the freezing of the milk increased extensibility and cutting force $(60 \%$ and $130 \%$, respectively, $p<0.05)$.

Table 3. Texture parameters of pasta filata cheeses from cow's and sheep's frozen milk.

\begin{tabular}{|c|c|c|c|c|c|c|}
\hline \multirow{2}{*}{ Parameters } & \multicolumn{5}{|c|}{ Pasta Filata Cheese } & \multirow{2}{*}{ SEM } \\
\hline & $\mathrm{C}$ & CS & CSF & $\mathrm{S}$ & SF & \\
\hline Extensibility force (g) & $35.4^{\mathrm{c}}$ & $33.8^{\mathrm{b}}$ & $37.4^{\mathrm{d}}$ & $26.6^{a}$ & $42.5^{\mathrm{e}}$ & 0.069 \\
\hline Stretching $(\mathrm{mm})$ & $127.8^{\mathrm{a}}$ & $131.4^{\mathrm{b}}$ & $129.8^{a}$ & $132.3^{b}$ & $133.1^{b}$ & 0.082 \\
\hline Hardness (g) & $264.3^{b}$ & $259.7^{b}$ & $322.8^{c}$ & $188.7^{\mathrm{a}}$ & $364.8^{d}$ & 0.042 \\
\hline Brittleness (mm) & $108.1^{\mathrm{a}}$ & $113.9^{b}$ & $108.9^{a}$ & $122.7^{\mathrm{c}}$ & $111.0^{\mathrm{b}}$ & 0.059 \\
\hline Cutting force (g) & $34.9^{c}$ & $30.6^{\mathrm{b}}$ & $41.4^{\mathrm{d}}$ & $23.7^{\mathrm{a}}$ & $54.8^{\mathrm{e}}$ & 0.045 \\
\hline
\end{tabular}

a-e Means within a row with different superscripts differ $(p<0.05)$; SEM: standard error of the mean $(n=5)$; C: from cow's milk, CS: from cow's and unfrozen sheep's milk in proportion 70:30; CSF: from cow's and frozen sheep's milk in proportion 70:30; S: from unfrozen sheep's milk; SF: from frozen sheep's milk. 
The addition of sheep's milk to cow's milk plays an important role in creating the cheese's texture. Reports have shown that it increased the hardness of reduced fat Muenstertype cheese [48]. Additionally, Everett and Auty [49] showed that the texture of cheeses was influenced by casein-casein, casein-water, and casein-fat interactions, the state of the water (bulk or bound to the casein matrix). Therefore, the texture parameters are important regarding the protein:fat ratio, as well as free oil formation. Addis et al. [50] found sheep's milk cheese with increased protein content in relation to fat was more compact, cohesive and hard. To supplement the knowledge about the interactions between the components, it is worth measuring water activity and water mobility. An understanding of mobile bulk water trapped within the casein matrix and a less mobile water phase bound directly to the casein will be given. This is important for explaining the diffusion of water molecules and fat globules in cheese. In the production of pasta filata cheeses, during the texturization process (heating, kneading and stretching), the elongation of protein fibers and aggregation of fat globules and pools of fat in the direction of stretching occurs. Water channels form between the casein fibers, which also elongate [51]. Fat globules in the channels compress during protein swelling. Sheep's milk has a lower fat globule size than cow's milk [33]. Overall, sheep's milk has good coagulation and cheese-making properties. Vacca et al. [52] determined the ingredient most associated with gelling, the hardening time of the curd and water retained in the curd, was lactose. Lactose strongly interacts with water, forming a water clustered structure with $\sim 123$ affected water molecules per lactose molecule [39]. Water and lactose form analogous complexes such as the interfacial ice-like water. Lactose governs the glass transition of most concentrated liquid milk products. Agranovich et al. [39] showed that with increasing competition for water, the nature of hydration around the lactose molecule changes, resulting in the water becoming even more ordered around the lactose molecule.

\subsection{Melt/Flow Profiles of Cheeses}

The freezing of milk reduces the meltability of pasta filata cheeses made from sheep's milk or mixed sheep's milk (Table $4, p<0.05$ ). Cheeses with the addition of nonfrozen sheep's milk had a higher meltability than those produced from cow's milk. When the frozen milk was added, the meltability of the cheeses in the tube test decreased $(p<0.05)$. Using only frozen sheep's milk cheeses, reduced meltability (tube test) by $11 \%(p<0.05)$ compared to that of cow's milk cheeses. The Schreiber test did not confirm such changes. Frozen sheep's milk cheese had $42 \%$ lower meltability (tube test) than nonfrozen sheep's milk cheese. Addition of some frozen sheep's milk, reduced the meltability (tube test) of the cheese by $20 \%$. This tendency was confirmed by the results of the Schreiber test. The flowability of pasta filata cheeses made entirely of frozen sheep's milk increased 12 -fold, whereas the mixture of milks increased 4-fold. No difference was found between the flowability of the cheese from the mixture with nonfrozen milk and cow's milk cheese $(p>0.05)$.

Table 4. Meltability (M) and flowability (F) parameters of pasta filata cheeses from cow's and sheep's frozen milk.

\begin{tabular}{|c|c|c|c|c|c|c|}
\hline \multirow{2}{*}{ Parameters } & \multicolumn{5}{|c|}{ Pasta Filata Cheese } & \multirow{2}{*}{ SEM } \\
\hline & $\mathrm{C}$ & CS & CSF & $\mathrm{S}$ & SF & \\
\hline $\mathrm{M}-$ Tube Test $(\mathrm{mm})$ & $7.2^{b}$ & $8.6^{c}$ & $6.9^{\mathrm{b}}$ & $11.1^{\mathrm{d}}$ & $6.4^{\mathrm{a}}$ & 0.043 \\
\hline M-Schreiber Test (scale 0-10) & $3.3^{\mathrm{a}}$ & $3.8^{\mathrm{b}}$ & $3.2^{\mathrm{a}}$ & $5.2^{\mathrm{c}}$ & $3.2^{\mathrm{a}}$ & 0.037 \\
\hline F-Oiling-off $(\%)$ & $3.13^{\mathrm{a}}$ & $2.92^{\mathrm{a}}$ & $11.56^{\mathrm{c}}$ & $4.21^{\mathrm{b}}$ & $51.85^{\mathrm{d}}$ & 0.001 \\
\hline
\end{tabular}

${ }^{\mathrm{a}-\mathrm{d}}$ Means within a row with different superscripts differ $(p<0.05)$; SEM: standard error of the mean $(n=5)$; C: from cow's milk; CS: from cow's and unfrozen sheep's milk in proportion 70:30; CSF: from cow's and frozen sheep's milk in proportion 70:30; S: from unfrozen sheep's milk; SF: from frozen sheep's milk.

The meltability and flowability of cheeses are important when cheeses are ingredients in food services. Upon heating of the cheese, the visual change is its softening and flow, where the proteins flow along with the melted fat [53]. Especially in pasta filata cheeses, 
the texture profile and melt/flow are more important than the taste as typical functional characteristics. If the freezing process is implemented, the range of changes is quite wide. Kuo and Gunasekaran [54] examined the effect of freezing and frozen storage of pasta filata cheese. They showed that after the freezing process (with tempering), the porosity of the cheese increased. As a result of tempering, water clusters are unable to fully rebind into proteins. This is what can lead to an increase in the porosity of the protein matrix. This also resulted in an increased meltability and decreased stretchability of pasta filata Mozzarella cheese.

\subsection{Characteristics of Water Distribution and Mobility in Cheese Based on Nuclear Magnetic Resonance (NMR) and Differential Scanning Calorimetry (DSC) Analysis}

Table 5 lists the DSC analysis of milk fat and ice melting phase transitions. The results of temperatures and enthalpies for the milk fat phase transition were calculated from the first and second melting curves of all the analyzed cheeses. The first heating curve was obtained during the heating of cheese samples from $5{ }^{\circ} \mathrm{C}$ to $70{ }^{\circ} \mathrm{C}$, and the second scan during heating from $-40^{\circ} \mathrm{C}$ to $70^{\circ} \mathrm{C}$ of samples previously cooled to $-40^{\circ} \mathrm{C}$. The presence of endothermic peaks proved that part of the milk fat was present at room temperature in the form of crystals in fat globules. The DSC parameters of temperatures and enthalpies calculated from first heating curves (Table 5) showed significant differences between the mean values of temperatures $\mathrm{TI}_{\text {onset }}$ and $\mathrm{TI}_{\text {peak }}$ as well as melting enthalpy $\Delta \mathrm{H}_{\mathrm{m} 1}$, however, temperature $\mathrm{TI}_{\text {end }}$ differences were not significant $(p>0.05)$. The highest values of melting enthalpy were measured for cheese from cow's and frozen sheep's milk (CSF sample), and the lowest for the cheese from cow's milk. A second heating of cheese samples enabled the observation of the melting phase transition without any thermal history, thus, the results of temperature and enthalpies differ from those of the first cycle of heating. However, the shape of the second heating curves did not differ for all types of cheese. Based on the DSC results from all the second heating cycles (Table 5) of all types of cheeses, we found that, similarly to the first heating curves, there were differences in all melting temperatures and enthalpies $(p<0.05)$. Only for samples $\mathrm{S}$ and SF, were the differences not significant in the case of enthalpy. Generally the results of melting enthalpy followed the pattern from the first heating cycle.

Table 5. Differential scanning calorimetry (DSC) parameters of pasta filata cheeses from cow's and sheep's unfrozen and frozen milk.

\begin{tabular}{|c|c|c|c|c|c|}
\hline \multirow{2}{*}{ Parameters } & \multicolumn{5}{|c|}{ Pasta Filata Cheese } \\
\hline & $\mathrm{C}$ & CS & CSF & $S$ & SF \\
\hline \multicolumn{6}{|l|}{ First heating } \\
\hline \multicolumn{6}{|l|}{ Temperature } \\
\hline $\mathrm{TI}_{\text {on }}\left({ }^{\circ} \mathrm{C}\right)$ & $11.78^{b}$ & $11.15^{\mathrm{ab}}$ & $10.27^{a b}$ & $11.78^{b}$ & $8.625^{a}$ \\
\hline $\mathrm{TI}_{\text {peak }}\left({ }^{\circ} \mathrm{C}\right)$ & $15.97^{c}$ & $13.15^{\mathrm{a}}$ & $16.88^{\mathrm{d}}$ & $13.85^{\mathrm{ab}}$ & $14.69^{b}$ \\
\hline $\mathrm{TI}_{\mathrm{end}}$ & $37.71^{\mathrm{a}}$ & $37.57^{\mathrm{a}}$ & $38.97^{a}$ & $36.54^{\mathrm{a}}$ & $37.36^{\mathrm{a}}$ \\
\hline Enthalpy $\Delta \mathrm{H}_{\mathrm{m} 1}(\mathrm{~J} / \mathrm{g}$ of fat) & $36.06^{\mathrm{a}}$ & $44.18^{\mathrm{ab}}$ & $84.43^{\mathrm{d}}$ & $57.72 \mathrm{bc}$ & $67.15^{\mathrm{cd}}$ \\
\hline \multicolumn{6}{|l|}{ Second heating } \\
\hline \multicolumn{6}{|l|}{ Temperature } \\
\hline $\mathrm{TII}_{\mathrm{on}}\left({ }^{\circ} \mathrm{C}\right)$ & $12.18^{c}$ & $7.92^{\mathrm{a}}$ & $12.61^{\mathrm{c}}$ & $7.43^{\mathrm{a}}$ & $10.60^{b}$ \\
\hline $\mathrm{TII}_{\text {peak }}\left({ }^{\circ} \mathrm{C}\right)$ & $15.88^{c}$ & $13.12^{\mathrm{a}}$ & $16.42^{c}$ & $13.29^{a}$ & $14.98^{b}$ \\
\hline $\mathrm{T}_{\text {end }}$ & $36.24^{b}$ & $34.01^{\mathrm{a}}$ & $36.59^{b}$ & $34.17^{\mathrm{a}}$ & $35.99^{b}$ \\
\hline Enthalpy $\Delta \mathrm{H}_{\mathrm{m} 2}$ (J/g of fat) & $41.95^{\mathrm{a}}$ & $70.88^{b}$ & $105.82^{d}$ & $85.39^{c}$ & $80.15^{c}$ \\
\hline \multicolumn{6}{|l|}{ Ice melting } \\
\hline \multicolumn{6}{|l|}{ Temperature } \\
\hline $\mathrm{Ti}_{\text {onset }}\left({ }^{\circ} \mathrm{C}\right)$ & $-4.14^{\mathrm{d}}$ & $-13.80^{\mathrm{c}}$ & $-13.27^{c}$ & $-19.92^{a}$ & $-16.50^{b}$ \\
\hline $\mathrm{Ti}_{\text {peak }}\left({ }^{\circ} \mathrm{C}\right)$ & $-0.11^{\mathrm{c}}$ & $-7.30^{b}$ & $-6.54^{b}$ & $-13.24^{\mathrm{a}}$ & $-7.57^{b}$ \\
\hline Enthalpy $\Delta \mathrm{H}_{\text {ice }}(\mathrm{J} / \mathrm{g}$ of water $)$ & $232.74^{c}$ & $100.36^{\mathrm{a}}$ & $99.77^{\mathrm{a}}$ & $90.16^{\mathrm{a}}$ & $153.85^{b}$ \\
\hline Unfreezable water (g/100 g of water) & $29.97^{a}$ & $69.80^{c}$ & $69.98^{c}$ & $72.87^{c}$ & $53.7^{\mathrm{b}}$ \\
\hline
\end{tabular}

${ }^{\mathrm{a}-\mathrm{d}}$ Means within a row with different superscripts differ $(p<0.05)$; C: from cows milk; CS: from cows and unfrozen sheep milk in proportion 70:30; CSF: from cows and frozen sheep milk in proportion 70:30; S: from unfrozen sheep milk; SF: from frozen sheep milk. 
During the second heating, the phase transition of ice melting in the cheese matrix was measured (Table 5). In the case of this phase transition it was possible to measure the amount of water frozen during cooling, which enabled the determination of unfrozen, bound water percentage. Significant differences were observed for temperatures and enthalpy of ice melting. The highest value of enthalpy $\Delta \mathrm{H}_{\mathrm{ice}}$ and higher of temperatures $\mathrm{Ti}_{\text {onset }}$ and $\mathrm{Ti}_{\text {peak }}$ for samples of cheese from cow's milk were obtained. These observations were in agreement with the results of moisture content shown in Table 2, where the highest value of moisture $(602.7 \mathrm{~g} / \mathrm{kg})$ was noted for cheese made from cow's milk. Table 5 shows the percentages of unfrozen water in the water fraction (UFW) of cheese, which were calculated according to Equation (2). The lowest percentage of UFW was found in cheese made from cow's milk, which was due to its lowest protein content (Table 2). In the case of the remaining cheese samples, the UFW level was similar except for cheese made from frozen sheep milk, where the value was lower than for cheese from unfrozen sheep's milk. The results were also in agreement with the increased water activity (Table 2) from 0.961 for cheese sample $S$ to 0.9773 for cheese sample SF. This indicated the influence of freezing on the binding of water, caused by changes in the protein's conformations.

Low-field nuclear magnetic resonance (LF NMR) methods can be used to observe the molecular properties of water in cheeses [55]. The values of spin-lattice T1 relaxation times reflected the relationship between bulk water and bound water fractions. As the amount of bulk fraction increased, the value of this relaxation time increased (Table 6). For cow's milk cheese, the most bulk water was observed compared to the bound fraction. Both fractions were also characterized by much greater molecular dynamics, which manifested in higher values of both components of spin-spin relaxation times. This was directly related to the protein content in milk [56]. Proteins are a natural water-binding biopolymer. Hence, a significantly lower value of this parameter should be obtained for sheep's milk cheese. The observed shortening of the spin-lattice relaxation times in cheeses containing sheep's milk after freezing was associated with a significant loss of water, as evidenced by increased $\mathrm{a}_{\mathrm{w}}$ value. The bound water fraction in cheeses containing sheep's milk had similar molecular dynamics. This confirmed the role of protein as a substance with water-binding properties. Analysis of the spin-spin relaxation time values describing the molecular dynamics of the bulk fraction (T22), revealed that the addition of previously frozen milk significantly changes the molecular dynamics of this fraction. The increased mobility of the bulk fraction could lead to easier evacuation of water from the system, which in turn, significantly affected the texture parameters.

Table 6. The values of the spin-lattice $T_{1}$ and both components of the spin-spin $T_{2}$ relaxation times in pasta filata cheeses from cow's and sheep's frozen milk.

\begin{tabular}{ccccccc}
\hline \multirow{2}{*}{ Relaxation Parameters } & \multicolumn{3}{c}{ Pasta Filata Cheese } & \multicolumn{1}{c}{ SEM } \\
\cline { 2 - 6 } & C & CS & CSF & S & SF & $121.3^{\mathrm{a}}$ \\
\hline $\mathrm{T}_{1}(\mathrm{~ms})$ & $279.3^{\mathrm{d}}$ & $228.4^{\mathrm{c}}$ & $120.9^{\mathrm{a}}$ & $125.9^{\mathrm{b}}$ & 0.206 \\
$\mathrm{~T}_{21}(\mathrm{~ms})$ & $24.1^{\mathrm{c}}$ & $10.8^{\mathrm{a}}$ & $10.7^{\mathrm{a}}$ & $10.9^{\mathrm{ab}}$ & $11.3^{\mathrm{b}}$ & 0.050 \\
$\mathrm{~T}_{22}(\mathrm{~ms})$ & $164.1^{\mathrm{e}}$ & $32.2^{\mathrm{a}}$ & $59.4^{\mathrm{b}}$ & $61.7^{\mathrm{c}}$ & $64.1^{\mathrm{d}}$ & 0.032 \\
\hline
\end{tabular}

${ }^{a-e}$ Means within a row with different superscripts differ $(p<0.05)$; SEM: standard error of the mean $(n=5)$; C: from cow's milk; CS: from cow's and unfrozen sheep's milk in proportion 70:30; CSF: from cow's and frozen sheep's milk in proportion 70:30; S: from unfrozen sheep's milk; SF: from frozen sheep's milk.

\subsection{Investigation of Consumer Perception}

Consumers showed the smallest differences between cow's milk cheese and cheese from the mixture with unfrozen sheep's milk (Table 7). In general, sheep's milk pasta filata cheeses were less accepted by consumers than cow's milk cheeses. Dissatisfaction (dislike) was even greater with frozen milk cheeses. The dislike responses for cheeses made only from sheep's milk increased from 7\% (nonfrozen milk) to 32\% (frozen milk). 
Table 7. Sensory acceptability of pasta filata cheeses from cow's and sheep's frozen milk.

\begin{tabular}{|c|c|c|c|c|c|c|}
\hline & & \multicolumn{5}{|c|}{ Pasta Filata Cheese } \\
\hline & & $\mathrm{C}$ & CS & CSF & $\mathrm{S}$ & SF \\
\hline 9 & Like extremely (\%) & 2.06 & 5.15 & 0 & 0 & 0 \\
\hline 8 & Like very much (\%) & 27.84 & 40.21 & 1.03 & 2.06 & 0 \\
\hline 7 & Like moderately (\%) & 30.93 & 35.05 & 28.87 & 40.21 & 0 \\
\hline 6 & Like slightly $(\%)$ & 11.34 & 1.03 & 39.18 & 21.65 & 17.53 \\
\hline 5 & Neither like nor dislike (\%) & 27.84 & 16.49 & 22.68 & 25.77 & 50.52 \\
\hline 4 & Dislike slightly (\%) & 0 & 2.06 & 6.19 & 3.09 & 15.46 \\
\hline 3 & Dislike moderately (\%) & 0 & 0 & 2.06 & 7.22 & 12.37 \\
\hline 2 & Dislike very much (\%) & 0 & 0 & 0 & 0 & 4.12 \\
\hline \multirow[t]{6}{*}{1} & Dislike extremely (\%) & 0 & 0 & 0 & 0 & 0 \\
\hline & Skewness & 0.66 & 1.28 & 1.09 & 1.22 & 2.02 \\
\hline & $p$-value & 0.005 & 0.004 & 0.009 & 0.018 & 0.003 \\
\hline & SD & 13.41 & 15.48 & 14.61 & 14.16 & 15.93 \\
\hline & $\mathrm{CV}$ & 124.38 & 143.65 & 135.55 & 131.36 & 147.78 \\
\hline & Dislike responses (\%) & 0 & 2.06 & 8.25 & 10.31 & 31.95 \\
\hline
\end{tabular}

SD: standard deviation; CV: coefficient of variation; C: from cow's milk; CS: from cow's and unfrozen sheep's milk in proportion 70:30; CSF: from cow's and frozen sheep's milk in proportion 70:30; S: from unfrozen sheep's milk; SF: from frozen sheep's milk.

The main reason for consumer dissatisfaction with cheeses made entirely or only with the addition of frozen milk was not enough of the qualities: refreshing (flavor), elasticity (texture), and shininess (appearance, Table 8). Freezing the milk changed the acidity (aroma) from not enough to too much. In contrast, in the case of sweet milk (aroma), it transitioned from too much to not enough.

Table 8. Consumer penalty analysis of the just-about-right (JAR) diagnostic attributes of pasta filata cheeses from cow's and sheep's frozen milk.

\begin{tabular}{|c|c|c|c|c|c|c|c|}
\hline & & & \multicolumn{5}{|c|}{ Pasta Filata Cheese } \\
\hline & & & $\mathrm{C}$ & CS & CSF & $S$ & SF \\
\hline \multirow[t]{2}{*}{ Aroma } & acidity & not enough & - & - & - & 14.43 & - \\
\hline & & too much & - & - & - & - & 13.40 \\
\hline \multirow[t]{4}{*}{ Flavor } & refreshing & not enough & - & - & 16.49 & 19.59 & 35.05 \\
\hline & & too much & - & - & - & - & - \\
\hline & sweet milk & not enough & - & - & - & - & 14.43 \\
\hline & & too much & - & - & - & 11.34 & - \\
\hline \multirow[t]{4}{*}{ Texture } & elasticity & not enough & - & - & 17.53 & - & 47.42 \\
\hline & & too much & - & - & - & - & - \\
\hline & smoothness & not enough & - & - & - & - & - \\
\hline & & too much & - & - & - & - & - \\
\hline \multirow[t]{2}{*}{ Appearance } & shininess & not enough & - & - & 17.53 & - & 24.74 \\
\hline & & too much & - & - & - & 12.37 & - \\
\hline
\end{tabular}

(-): indicates that less than 10\% of consumers chose that JAR category; C: from cow's milk; CS: from cow's and unfrozen sheep's milk in proportion 70:30; CSF: from cow's and frozen sheep's milk in proportion 70:30; S: from unfrozen sheep's milk; SF: from frozen sheep's milk.

The consumer penalty analysis of just-about-right (JAR) did not reveal differences only between cow's milk cheese and cheese with the addition of unfrozen sheep's milk. Unfrozen sheep's milk cheeses generally had not enough: acidity (aroma), refreshing (flavor); and too much: sweet milk (flavor) shininess (appearance) compared to cow's milk cheeses. Importantly, more than $10 \%$ of consumers chose the JAR category.

Faccia et al. [32] found pasta filata cheese made of sheep's milk compared to cow's milk had more milk odor and flavor, was less elastic and rubbery (texture during chewing), and was more slippery. This was due to the different behavior of the curds during stretching. They showed porcelainity (external appearance) as a peculiar characteristic, while cow's cheeses were not shiny. In our study, pasta filata cheeses made from sheep's milk had (according to the consumer penalty analysis of the JAR) too much shininess $(12.37 \%)$. Pasta 
filata Caciocavallo cheese produced by Niro et al. [21] from the mixture of cow's and sheep's milk $(82: 18, v / v)$ compared to cow's cheese was less sweet, saltier, less elastic, more friable and harder. Increased hardness was also demonstrated by Aminifar et al. [57].

\section{Conclusions}

The production of pasta filata cheese from frozen sheep's milk was not a good alternative to using the raw material. The new cheeses were not fully accepted by consumers. This creates big constraints for development and innovation in the small ruminant dairy sector. Frozen/thawed sheep's milk did not appear to contribute to the development of innovative and reformulated cheeses. The rationale was the changes in the texture and meltability profile of cheeses made entirely of frozen sheep's milk or only with $30 \%$ in a mixture with cow's milk. The addition of frozen milk reduced stretching, which was the most characteristic feature of pasta filata cheeses. The freezing of milk makes cheeses, made entirely or with partial addition, harder and brittle, less stretchy and less elastic. These cheeses had the highest values of melting enthalpy measured. The level of unfrozen water in the water fraction was similar except for the cheese made from frozen sheep's milk, where the value was lower than for cheese from unfrozen sheep's milk. This result was also justified by increased water activity. Therefore, freezing influenced the binding of water, caused by the changes in protein conformations. At the same time, their flowability increased, which probably had a decisive influence on the overall appearance of the cheeses. The use of frozen milk significantly increased the number of dissatisfied consumers. The consumer penalty analysis of the just-about-right scale showed that freezing milk caused the loss of the refreshing, elasticity and shininess qualities of the produced pasta filata cheeses. Additionally, in cheeses made only from frozen milk, aroma acidity was intensified and the sweet-milk flavor disappeared. Our results can be the basis for research into the use of sheep's milk as an addition in dairy technologies other than cheese making and for research on the use of frozen sheep's milk. The results of our research could be an interesting and real opportunity for the dairy industry, allowing for market expansion of sheep's milk.

Author Contributions: Conceptualization, J.B. and D.C.-S.; methodology, J.B. and D.C.-S.; software, J.B.; validation, J.B. and J.T.-G.; formal analysis, J.B. and D.C.-S.; investigation, J.T.-G. and H.M.B.; resources, D.C.-S.; data curation, H.M.B.; writing-original draft preparation, J.B. and D.C.-S.; writing - review and editing, J.B.; visualization, J.B.; funding acquisition, D.C.-S. All authors have read and agreed to the published version of the manuscript.

Funding: A part of the study was supported by grant No. 506.784.03.00/UPP-KJPM from the Ministry of Education and Science (Poznań, Poland).

Institutional Review Board Statement: This article does not contain any studies with human or animal subjects.

Informed Consent Statement: Informed consent was obtained from all subjects involved in the study.

Data Availability Statement: The authors confirm that the data supporting the findings of this study are available within the article.

Conflicts of Interest: The authors declare no conflict of interest.

\section{References}

1. Tribst, A.A.L.; Ribeiro, L.R.; de Castro Leite Júnior, B.R.; de Oliveira, M.M.; Cristianini, M. Fermentation profile and characteristics of yoghurt manufactured from frozen sheep milk. Int. Dairy J. 2018, 78, 36-45. [CrossRef]

2. FAOSTAT Statistical Database. Crops and Livestock Products, World Production Quantity of Whole Fresh, Sheep Milk in 2019. Available online: http://www.fao.org/faostat/en/\#data/QCL (accessed on 6 May 2021).

3. Nudda, A.; Atzori, A.S.; Correddu, F.; Battacone, G.; Lunesu, M.F.; Cannas, A.; Pulina, G. Effects of nutrition on main components of sheep milk. Small Rumin. Res. 2020, 184, 106015. [CrossRef]

4. Balthazar, C.F.; Pimentel, T.C.; Ferrão, L.L.; Almada, C.N.; Santillo, A.; Albenzio, M.; Mollakhalili, N.; Mortazavian, A.M.; Nascimento, J.S.; Silva, M.C.; et al. Sheep Milk: Physicochemical characteristics and relevance for functional food development. Compr. Rev. Food Sci. Food Saf. 2017, 16, 247-262. [CrossRef] [PubMed] 
5. Renes, E.; Fernández, D.; Abarquero, D.; Ladero, V.; Álvarez, M.A.; Tornadijo, M.E.; Fresno, J.M. Effect of forage type, season, and ripening time on selected quality properties of sheep milk cheese. J. Dairy Sci. 2021, 104, 2539-2552. [CrossRef]

6. Haenlein, G.F.W. Past, present, and future perspectives of small ruminant dairy research. J. Dairy Sci. 2001, 84, 2097-2115. [CrossRef]

7. Mohapatra, A.; Shinde, A.K.; Singh, R. Sheep milk: A pertinent functional food. Small Rumin. Res. 2019, 181, 6-11. [CrossRef]

8. Cais-Sokolińska, D.; Wójtowski, J.; Pikul, J. Lactose hydrolysis and lactase activity in fermented mixtures containing mare's, cow's, sheep's and goat's milk. Int. J. Food Sci. Technol. 2016, 51, 2140-2148. [CrossRef]

9. Cais-Sokolińska, D.; Wójtowski, J.; Pikul, J. Rheological, texture and sensory properties of kefir from mare's milk and its mixtures with goat and sheep milk. Mljekarstvo 2016, 66, 272-281. [CrossRef]

10. Boukria, O.; El Hadrami, E.M.; Boudalia, S.; Safarov, J.; Leriche, F.; Aït-Kaddour, A. The effect of mixing milk of different species on chemical, physicochemical, and sensory features of cheeses: A Review. Foods. 2020, 9, 1309. [CrossRef] [PubMed]

11. Alichanidis, E.; Moatsou, G.; Polychroniadou, A. Composition and properties of non-cow milk and products. In Non-Bovine Milk and Milk Products; Tsakalidou, E., Papadimitriou, K., Eds.; Academic Press: London, UK, 2016; pp. 81-116. [CrossRef]

12. Moatsou, G.; Sakkas, L. Sheep milk components: Focus on nutritional advantages and biofunctional potential. Small Rumin. Res. 2019, 180, 86-99. [CrossRef]

13. Raynal-Ljutovac, K.; Park, Y.W.; Gaucheron, F.; Bouhallab, S. Heat stability and enzymatic modifications of goat and sheep milk. Small Rumin. Res. 2007, 68, 207-220. [CrossRef]

14. Tribst, A.A.L.; Falcade, L.T.P.; Ribeiro, L.R.; de Castro Leite Júnior, B.R.; de Oliveira, M.M. Impact of extended refrigerated storage and freezing/thawing storage combination on physicochemical and microstructural characteristics of raw whole and skimmed sheep milk. Int. Dairy J. 2019, 94, 29-37. [CrossRef]

15. Wendorff, W.L.; Kalit, S. Processing of sheep milk, In Handbook of Milk of Non-Bovine Mammals, 2nd ed.; Park, Y.W., Haenlein, G.F.W., Wendorff, W.L., Eds.; John Wiley \& Sons, Ltd.: Hoboken, NJ, USA, 2017; pp. 222-260. [CrossRef]

16. Zhang, R.H.; Mustafa, A.F.; Ng-Kwai-Hang, K.F.; Zhao, X. Effects of freezing on composition and fatty acid profiles of sheep milk and cheese. Small Rumin. Res. 2006, 64, 203-210. [CrossRef]

17. Pazzolla, M.; Dettori, M.L.; Manca, F.; Noce, A.; Piras, G.; Pira, E.; Puggioni, O.; Vacca, G.M. The effect of long-term freezing on renneting properties of sarda sheep milk. Agric. Conspec. Sci. 2013, 78, 275-279.

18. Wendorff, W.L. Freezing qualities of raw ovine milk for further processing. J. Dairy Sci. 2001, 84, E74-E78. [CrossRef]

19. Albenzio, M.; Santillo, A.; Caroprese, M.; Braghieri, A.; Sevi, A.; Napolitano, F. Composition and sensory profiling of probiotic Scamorza ewe milk cheese. J. Dairy Sci. 2013, 96, 2792-2800. [CrossRef] [PubMed]

20. Tripaldi, C.; Palocci, G.; Di Giovanni, S.; Marri, N.; Boselli, C.; Giangolini, G.; Amatiste, S. Microbiological and chemical characteristics of pasta filata type cheese from raw ewe milk, using thermophilic and mesophilic starters. Arch Lebensmittelhyg 2018, 69, 123-129.

21. Niro, S.; Fratianni, A.; Tremonte, P.; Sorrentino, E.; Tipaldi, L.; Panfili, G.; Coppola, R. Innovative Caciocavallo cheeses made from a mixture of cow milk with ewe or goat milk. J. Dairy Sci. 2014, 97, 1296-1304. [CrossRef]

22. International Dairy Federation. Cheese and Processed Cheese Products: Determination of Dry Matter; IDF 1986, Standard 4; International Dairy Federation (IDF): Brussels, Belgium, 1986.

23. International Organization for Standardization. Milk and Milk Products—Guidelines for the Application of Near Infrared Spectrometry; ISO 21543 [IDF 201:2020]; International Organization for Standardization: Geneva, Switzerland, 2020.

24. International Organization for Standardization. Milk Determination of Freezing Point-Thermistor Cryoscope Method (Reference Method); ISO 5764 [IDF 108:2009]; International Organization for Standardization: Geneva, Switzerland, 2009.

25. Cais-Sokolińska, D.; Bierzuńska, P.; Kaczyński, Ł.K.; Baranowska, H.M.; Tomaszewska-Gras, J. Stability of texture, meltability and water mobility model of pizza-style cheeses from goat's milk. J. Food Eng. 2018, 222, 226-236. [CrossRef]

26. Schenkel, P.; Samudrala, R.; Hinrichs, J. Thermo-physical properties of semi-hard cheese made with different fat fractions: Influence of melting point and fat globule size. Int. Dairy J. 2013, 30, 79-87. [CrossRef]

27. Hartmann, K.I.; Samudrala, R.; Hofmann, T.; Schieberle, P.; Hitzmann, B.; Hinrichs, J. Thermo-physical parameters applied for instrumental profiling and statistical evaluation of German Emmental cheese. Int. Dairy J. 2015, 49, 118-124. [CrossRef]

28. Weglarz, W.P.; Harańczyk, H. Two-dimensional analysis of the nuclear relaxation function in the time domain: The program CracSpin. J. Phys. D. Appl. Phys. 2000, 33, 1909-1920. [CrossRef]

29. Baranowska, H.M.; Tomaszewska-Gras, J.; Cais-Sokolińska, D.; Bierzuńska, P.; Kaczyński, Ł.K. Water mobility and thermal properties of smoked soft cheese. Mljekarstvo 2017, 67, 188-196. [CrossRef]

30. Caboni, P.; Maxia, D.; Scano, P.; Addis, M.; Dedola, A.; Pes, M.; Murgia, A.; Casula, M.; Profumo, A.; Pirisi, A. A gas chromatography-mass spectrometry untargeted metabolomics approach to discriminate Fiore Sardo cheese produced from raw or thermized ovine milk. Int. J. Dairy Sci. 2019, 102, 5005-5018. [CrossRef]

31. Bučević-Popović, V.; Delaš, I.; Međugorac, S.; Pavela-Vrančić, M.; Kulišić-Bilušić, T. Oxidative stability and antioxidant activity of bovine, caprine, ovine and asinine milk. Int. J. Dairy Technol. 2014, 67, 394-401. [CrossRef]

32. Faccia, M.; Trani, A.; Gambacorta, G.; Loizzo, P.; Cassone, A.; Caponio, F. Production technology and characterization of Fior di latte cheeses made from sheep and goat milks. J. Dairy Sci. 2014, 98, 1402-1410. [CrossRef] [PubMed] 
33. Tribst, A.A.L.; Falcade, L.T.P.; Carvalho, N.S.; de Castro Leite Júnior, B.R.; de Oliveira, M.M. Using stirring and homogenization to improve the fermentation profile and physicochemical characteristics of set yogurt from fresh, refrigerated and frozen/thawed sheep milk. LWT 2020, 130, 109557. [CrossRef]

34. Sánchez, A.F.; Muñoz, J.P.; Caballero-Villalobos, J.; Sánchez, R.A.; Garzón, A.; Sánchez de Pedro, E.A. Coagulation process in Manchega sheep milk from Spain: A path analysis approach. J. Dairy Sci. 2021, 104, 7544-7554. [CrossRef]

35. Yanthi, N.D.; Said, S.; Anggraeni, A.; Damayanti, R. Correlation of electric conductivity values with the dairy milk quality. JITV 2018, 32, 82-88. [CrossRef]

36. Kaşikçi, G.; Çetin, Ö.; Bingöl, E.B.; Gündüz, M.C. Relations between electrical conductivity, somatic cell count, California mastitis test and some quality parameters in the diagnosis of subclinical mastitis in dairy cows. Turkish J. Vet. Anim. Sci. 2012, 36, 49-55.

37. Qayyum, A.; Khan, J.A.; Hussain, R.; Avais, M.; Ahmad, N.; Sarwar-Khan, M. Investigation of milk and blood serum biochemical profile as an indicator of sub-clinical mastitis in Cholistani cattle. Pak. Vet. J. 2016, 36, 275-279.

38. Fahmid, S.; Hassan, E.; Naeem, H.; Barrech, S.; Lodhi, S.; Latif, S. Determination of mastitis by measuring milk electrical conductivity. Int. J. Adv. Res. Biol. Sci. 2016, 3, 1-4.

39. Agranovich, D.; Ishai, P.B.; Katz, G.; Bezman, D.; Feldman, Y. Dielectric spectroscopy study of water dynamics in frozen bovine milk. Colloids Surf. B. 2016, 141, 390-396. [CrossRef]

40. The Codex Alimentarius Commission Codex Stan 262. Codex General Standard for Mozzarella; WHO/FAO International Food Standards: Rome, Italy, 2019.

41. Yu, Z.; Qiao, C.; Zhang, X.; Yan, L.; Li, L.; Liu, Y. Screening of frozen-thawed conditions for keeping nutritive compositions and physicochemical characteristics of goat milk. J. Dairy Sci. 2021, 104, 4108-4118. [CrossRef] [PubMed]

42. Suranindyah, Y.; Pretiwi, P. Quality and emulsion stability of milk from Ettawah crossed bred goat during frozen storage. Procedia Food Sci. 2015, 3, 142-149. [CrossRef]

43. Katsiari, M.C.; Voutsinas, L.P.; Kondyli, E. Manufacture of yoghurt from stored frozen sheep's milk. Food Chem. 2002, 77, 413-420. [CrossRef]

44. Voutsinas, L.P.; Katsiari, M.C.; Pappas, C.P.; Mallatou, H. Production of brined soft cheese from frozen ultrafiltered sheep's milk. Part 2 compositional, physicochemical, microbiological and organoleptic properties of cheese. Food Chem. 1995, 52, $235-247$. [CrossRef]

45. Kindstedt, P.S.; Hillier, A.J.; Mayes, J.J. Technology, biochemistry and functionality of pasta filata/pizza cheese. In Technology of Cheesemaking; Law, B.A., Tamime, A.Y., Eds.; Blackwell Publishing: Hoboken, NJ, USA, 2010; pp. 330-352. [CrossRef]

46. Kljajevic, N.V.; Jovanovic, S.T.; Miloradovic, Z.N.; Macej, O.D.; Vucic, T.R.; Zdravkovic, I.R. Influence of the frozen storage period on the coaglation properties of caprine milk. Int. Dairy J. 2016, 58, 36-38. [CrossRef]

47. Tribst, A.A.L.; Falcade, L.T.P.; de Oliveira, M.M. Strategies for raw sheep milk storage in smallholdings: Effect of freezing or long-term refrigerated storage on microbial growth. J. Dairy Sci. 2019, 102, 4960-4971. [CrossRef]

48. Ponce de Leon-Gonzalez, L.; Wendorff, W.L.; Ingham, B.H.; Thomas, D.L.; Jaeggi, J.J.; Houck, K.B. Influence of ovine milk in mixture with bovine milk on the quality of reduced fat Muenster-type cheese. J. Dairy Sci. 2002, 85, 36-42. [CrossRef]

49. Everett, D.W.; Auty, M.A.E. Cheese structure and current methods of analysis. Int. Dairy J. 2008, 18, 759-773. [CrossRef]

50. Addis, M.; Pes, M.; Fiori, M.; Nieddu, G.; Furesi, S.; Pirisi, A. Effect of protein-to-fat ratio of sheep milk on the composition, rheological properties and yield of PDO Pecorino Romano cheese. Small Rumin. Res. 2018, 162, 1-7. [CrossRef]

51. Joshi, N.S.; Muthukumarappan, K.; Dave, R.I. Effect of calcium on microstructure and meltability of part skim Mozzarella cheese. J. Dairy Sci. 2004, 87, 1975-1985. [CrossRef]

52. Vacca, G.M.; Cipolat-Gotet, C.; Paschino, P.; Casu, S.; Usai, M.G.; Bittante, G.; Pazzola, M. Variation of milk technological properties in sheep milk: Relationships among composition, coagulation and cheese-making traits. Int. Dairy J. 2019, 97, 5-14. [CrossRef]

53. Ko, S.; Gunasekaran, S. Evaluation of cheese meltability using convection and conduction melt profilers. Int. J. Dairy Technol. 2014, 67, 194-201. [CrossRef]

54. Kuo, M.-I.; Gunasekaran, S. Effect of freezing and frozen storage on microstructure of Mozzarella and pizza cheeses. LWT 2009, 42, 9-16. [CrossRef]

55. Gianferri, R.; Maioli, M.; Delfini, M.; Brosio, E. A low-resolution and high-resolution nuclear magnetic resonance integrated approach to investigate the physical structure and metabolic profile of Mozzarella di Bufala Campana cheese. Int. Dairy J. 2007, 17, 167-176. [CrossRef]

56. Boiani, M.; Sundekilde, U.; Bateman, L.M.; McCarthy, D.G.; Maguire, A.R.; Gulati, A.; Guinee, T.P.; Fenelon, M.; Hennessy, D.; FitzGerald, R.J.; et al. Integration of high and low field ${ }^{1} \mathrm{H}$ NMR to analyse the effects of bovine dietary regime on milk metabolomics and protein-bound moisture characterisation of the resulting mozzarella cheeses during ripening. Int. Dairy J. 2019, 91, 155-164. [CrossRef]

57. Aminifar, M.; Hamedi, M.; Emam-Djomeh, Z.; Mehdinia, A. The effect of ovine and bovine milk on the textural properties of Lighvan cheese during ripening. Int. J. Dairy Technol. 2012, 66, 45-53. [CrossRef] 